\title{
PESANTREN DAN PENGEMBANGAN STUDI ISLAM BERWAWASAN GENDER
}

\author{
Rahmat Fauzi, Ali Marzuki Zebua
}

\author{
Institut Agama Islam Negeri Kerinci \\ Jl. Pelita IV, Sumur Gedang, Kerinci, Jambi \\ e-mail: ziel.rahmat@gmail.com, alimarzukizebua@iainkerinci.ac.id
}

\begin{abstract}
Abstrak: Artikel ini membahas tentang upaya dan strategi pengembangan ilmu agama Islam di pesantren yang berwawasan gender. Kajian sebelumnya tentang gender dan pesantren lebih menitikberatkan pada dimensi sosial budaya gender, relasi kekuasaan, pemberdayaan perempuan, citra perempuan dalam kitab kuning, tokoh dan instansi. Namun demikian, ada beberapa penelitian yang mencoba mengkaji upaya pengembangan pendidikan pesantren berbasis gender di tingkat kelembagaan formal. Sangat sedikit yang menganalisis upaya pengembangan kajian Islam berbasis gender di dunia pesantren. Hal ini lebih disebabkan karena beberapa pengasuh pesantren sulit menerima konsep kesetaraan gender, yang menurut mereka bukan berasal dari badan keilmuan Islam. Dengan menggunakan pendekatan interkoneksi-integrasi yang dikembangkan oleh Amin Abdullah dan Jasser Auda, makalah ini menjelaskan bahwa pengembangan kajian Islam di pesantren sangat mendesak dilakukan dengan memanfaatkan konsep-konsep yang relevan dari ilmu-ilmu lain seperti budaya, sosial, ekonomi, psikologis dan sebagainya. Melalui apa yang disebut interkoneksi ilmiah, wawasan gender Islam yang baru dapat dikembangkan dan dipahami secara lebih holistik dan kontekstual di lingkungan akademik pesantren.
\end{abstract}

Kata Kunci: Gender, Integrasi-Interkoneksi, Pesantren, Studi Islam

\begin{abstract}
This article discusses efforts and strategies for developing Islamic studies in Islamic boarding schools that have gender insight. Previous studies on gender and Islamic boarding schools focused more on the socio-cultural dimensions of gender, power relations, women's empowerment, the image of women in the yellow book, figures and agencies. However, there are several studies that have tried to examine efforts to develop gender-based pesantren education at the formal institutional level. Very few have analyzed efforts to develop gender-based Islamic studies in the world of pesantren. This is more due to the difficulty in accepting some pesantren caregivers of the concept of gender equality, which according to them does not come from an Islamic scientific body. Using the integration-interconnection approach developed by Amin Abdullah and Jasser Auda, this paper explains that the development of Islamic studies in pesantren is urgently carried out by utilizing relevant concepts from other sciences such as cultural, social, economic, psychological and so on. Through the so-called scientific interconnections, new Islamic gender insights can be developed and understood more holistically and contextually in the academic environment of the pesantren.
\end{abstract}

Keywords: Gender, Integration-Interconection, Pesantren, Islamic Studies

\section{PENDAHULUAN}

Ketidakadilan gender yang

bertentangan dengan nilai moral Islam telah menjadi common sense yang dipraktikkan dalam ranah private atau domestik maupun publik. Kendati persoalan ini telah 
mendapat perhatian serius dari berbagai tokoh yang disuarakan lewat berbagai karya hingga aksi masa (Tokoh-tokoh tersebut antara lain Qosim Amin (w. 1908), Ashgar Ali (w, 2013), Riffat Hassan, Amina Wadud, Fatimah Mernissi, Hussein Muhammad, Musdah Mulia, dan banyak lagi), tetap saja kasus-kasus marginalisasi perempuan terus mencuat ke permukaan. Ketimpangan tersebut tidak dapat dipungkiri lahir di antaranya dari rahim tradisi keilmuan Islam yang sebagian besar ditransmisikan via sekolah, madrasah dan pesantren.

Kitab-kitab tafsir, hadis, dan fiqh yang memuat pemahaman bias gender mengisi secara dominan ruang-ruang akademis. Adalah tidak sulit untuk menemukan, dalam literatur-literatur keIslaman klasik bahkan kontemporer, dari masa pra-Quranik sampai pasca-Quranik semisal dalam penelitian Harahap, dkk (Harahap, Pujiati, and Zebua 2020) menyatakan bahwa "the women was understood as being helpless, weak and oppressed in pre-Qur'anic period"; para perempuan pada periode sebelum al-Quran dianggap tidak berdaya, lemah dan tertindas. Sedangkan di masa pra-Quranik isu-isu yang mendiskreditkan perempuan semisal status, wilayah dan pembagian kerja, kebebasan menentukan keputusan, kesetaraan hak dalam hukum dan sebagainya semakin meningkat. Pembelajaran yang berkelanjutan mengenai bias gender ini, tanpa studi kritis akan semakin memposisikan perempuan dalam pihak yang marginal dan inferior.
Eka Srimulyani dalam penelitiannya menemukan bahwa pesantren-pesantren khusus perempuan secara garis besar didesain untuk mempersiapkan masa depan para perempuan yang mampu menjadi seorang ibu (dalam pemahaman budaya patriarkhi). Dalam artian tersebut orientasi pesantren ialah menciptakan perempuan yang terampil dalam berbagai pekerjaan rumah tangga, mengurus anak hingga melayani suami (Srimulyani 2007). Ada banyak ayat al-Quran, Hadis dan penafsiran ulama yang dijadikan basis pembenaran semisal teks-teks yang menyatakan bahwa perempuan diciptakan dari tulang rusuk nabi adam, perempuan sebagai alat reproduksi serta objek seks laki-laki, dan sebagainya (Marcoes and Meuleman 1993:159).

Hussein Muhammad, terkenal sebagai Kyai Feminist Indonesia, menyebut bahwa salah satu akar ketidakadilan gender ialah penafsiran atas al-Quran dan Hadis yang bias laki-laki. Pembacaan keliru tersebut diwarisi ke dalam kitab fikih, tafsir, syarah hadis yang dipelajari dan diamalkan dari generasi ke generasi sebagai konsep final yang tidak dapat diubah. Memahami hal tersebut, sebagai seorang Kyai dan Pengasuh pesantren, Hussein Muhammad telah melakukan upaya serius agar kesetaraan dan keadilan gender dapat terealisasi lewat tulisan maupun aktivisme. seperti misalnya ia menulis artikel secara rinci mengenai pemikiran dan aktivisme Husein Muhammad tentang isu gender.

Beberapa studi mengenai gender dan pesantren telah banyak dilakukan. Setidaknya studi-studi tersebut dapat 
dikategorikan menjadi tiga kelompok. Pertama, Studi yang mencoba menganalisa aspek sosial gender di lingkungan pesantren. Kedua, penelitian yang mencoba memetakan posisi perempuan di dalam kitab kitab kuning yang umum dijadikan sebagai bahan ajar di lingkungan pesantren. Ketiga, kajian yang membahas persoalan tokoh atau agency. Tulisan-tulisan yang secara fokus mengkaji pengembangan studi Islam yang berwawasan gender di lingkungan pesantren terlihat belum dilakukan secara intens dan optimal. Dengan menggunakan pendekatan integrasi interkoneksi, tulisan ini fokus mendiskusikan upaya pengembangan studi Islam yang terhubung dan terintegrasi dengan disiplin keilmuan lain. Dalam artian tersebut hasil fatwa, tafsir atau penjelasan hadis mengenai gender yang dipelajari dari kitab-kitab kuning di pesantren perlu dipahami secara lebih holistik dengan memanfaatkan disiplin keilmuan lain yang relevan.

Tulisan ini berangkat dari dua argumentasi dasar. Pertama, ketidakadilan gender lahir dari kondisi sosial kultural yang diperoleh salah satunya dari ajaran keagamaan di lingkungan pesantren. Kedua, kitab-kitab kuning yang dipelajari di pesantren hampir seluruhnya ditulis oleh ulama laki-laki yang mencitrakan subjektifitas kelaki-lakiannya, selain juga sangat dipengaruhi oleh budaya patriarkhal sebagai setting sosio-historis. Oleh sebab itu, diperlukan gagasan pengembangan studi Islam yang integratif dan kritis sekaligus berwawasan gender di lingkungan pesantren untuk memutus lingkaran ketidakadilan berbasis gender.

\section{DISKURSUS GENDER DALAM LITERATUR KEISLAMAN}

$\begin{array}{ccr}\text { Pesantren } & \text { merupakan } & \text { tempat } \\ \text { dilaksanakannya } & \text { pendidikan } & \text { dan }\end{array}$ pengajaran yang berkonsentrasi pada kajian keIslaman, kendati dewasa ini ilmu-ilmu umum juga telah mendapatkan perhatian yang cukup serius. Selain menyediakan sarana pra-sarana pembelajaran, umumnya pesantren memfasilitasi bahkan mewajibkan para pelajarnya untuk menginap di asrama (boarding school). Hal itu disebabkan bahwa di asrama para pelajar dapat memperoleh pelajaran tambahan, selain juga melatih kemandirian dan akhlak para pelajar. Menurut Zamakhsari Dhofier (Dhofier 1982:49-51), ada lima elemen yang saling terhubung di pesantren. Pertama, Asrama atau pondok, tempat para pelajar (santri) menginap. Kedua, Mesjid, sebagai pusat aktivitas tempat para santri melaksanakan ritual agama dan menuntut ilmu. Ketiga, murid atau dalam tradisi pesantren biasa disebut sebagai santri. Keempat, Kyai sebagai pengasuh dan pengajar. Kelima, pembelajaran kitab kuning sebagai media memperoleh ajaran agama. Elemen yang terakhir ini menempati posisi sentral tidak hanya bagi pesantren sebagai sebuah institusi pendidikan tetapi juga dalam proses transmisi Islam tradisional di Indonesia pada umumnya.

Kendati demikian patut disayangkan bahwa ilmu-ilmu yang termuat di dalam kitab kuning diterima begitu saja 
(doktrinasi) dan dianggap sebagai pengetahuan final oleh banyak tokoh pesantren. Martin Van Bruinessen (Bruinessen 2012:85) mencatat:

Salah satu Tradisi besar di Indonesia adalah tradisi pengajaran agama Islam seperti yang muncul di pesantren. Alasan utama berdirinya pesantren ialah untuk mentransmisikan Islam tradisional sebagaimana yang termuat dalam kitabkitab klasik yang ditulis berabad-abad yang lalu. Kitab-kitab ini di Indonesia dikenal sebagai kitab kuning. Jumlah teks klasik yang dipelajari di pesantren sebagai ortodoks pada dasarnya terbatas. Ilmu yang bersangkutan dianggap sesuatu yang sudah final dan tidak dapat diubah; hanya bisa dijelaskan dan direkonstruksi. Kekakuan tradisi itu sebenarnya telah banyak dikritik baik oleh akademisi asing maupun kaum muslim reformis dan modernis.

Persoalan gender dalam wacana agama sebagaimana tertuang dalam kitabkitab tafsir, fikih, hadis, ilmu kalam dan tasawuf (kitab kuning), menjadi salah satu tema kajian yang dianggap telah final di lingkungan pesantren; sebuah konsep yang tidak perlu diuji atau dipahami ulang. Meski tidak sedikit intelektual Islam telah membuktikan berbagai kekeliruan penafsiran dan kesalahan metode berpikir serta ketidaksesuaian teks dan konsep di dalamnya dengan spirit universal Islam tetap saja para kyai-kyai pesantren menilai sebaliknya. Bagi mereka selama ilmu tersebut berangkat dari al-Quran dan Hadis ia wajib diyakini kebenarannya karena merupakan bagian dari perintah agama. Mereka tidak membedakan antara Islam dan studi Islam, antara al-Quran dan tafsir al-Quran, antara hadis dan syarah hadis (Muhammad 2016:63-64). Padahal proses pembacaan atas teks tidak pernah berangkat dari ruang kosong. Sebab itulah dalam hermeneutika (juga dalam sosiologi pengetahuan) dikenal istilah 'ketersituasian pembaca', artinya sebuah karya yang dihasilkan sangat dipengaruhi oleh kondisi sosial-kultural, kecenderungan politis dan latar belakang keilmuan penulis.

Adapun gagasan gender dalam kitab kuning tertuang ke dalam beberapa objek dan tekanan sesuai arah konspetual masingmasing disiplin ilmu. Pada kajian hukum Islam atau fikih, isu gender dapat berkaitan dengan persoalan ibadah dan aturan formal. Pada disiplin keilmuan tafsir serta hadis wacana gender bisa berhubungan dengan berbagai topik semisal sosial, politik, akhlak dan sebagainya. Lalu pada kajian tasawuf, pembicaraan lebih banyak terarah pada aspek spritual. Contoh representasi perempuan dan bias laki-laki dalam fikih yang banyak dipelajari di berbagai pesantren ialah kitab berjudul 'Uqud alLujjayn (Nawawi n.d.). Kitab ini misalnya menyinggung ketidakberdayaan perempuan dalam mengendalikan tubuh dan kehendaknya di hadapan laki-laki atau suaminya (Nawawi n.d.:2-23). Guna melegitimasi pandangannya, dikutip beberapa hadis semisal: "Suatu ketika datanglah seorang perempuan kepada Nabi dan menceritakan bahwa ia tengah menerima lamaran dari saudara sepupunya sehingga ia menghadap Nabi agar diberitahukan tentang kewajiban seorang istri terhadap suami. Kalau aku mampu 
melakukannya, maka akan menerima lamarannya. Maka Nabi menjawab: "Andai saja engkau menjilati tubuh suamimu yang berlumuran darah dan nanah, maka itu sama sekali belum memenuhi haknya atasmu. Andai saja seorang hamba boleh bersujud pada seorang manusia maka akan aku perintahkan seorang istri untuk bersujud pada suaminya”. Bertolak dari itu Forum Kajian Kitab Kuning (FK3) yang dikepalai oleh Sinta Nuriah Wahid telah melontarkan kritikan. Berdasarkan hasil penelitian mereka kitab ini memuat 33\% hadis palsu, 22\% hadis dhaif dan selebihnya berstatus shahih dan hasan. Sebagai tambahan mereka menyebut bahwa tidak semua hadis yang shahih sanadnya, shahih juga matannya.

Sementara ada banyak contoh dalam literatur tafsir yang memposisikan perempuan sebagai pihak inferior. Tulisan Nasarudin Umar dan Amany Lubis berjudul Hawa Sebagai Simbol Ketergantungan: Relasi Gender Dalam Kitab Tafsir dalam Munhanif (Munhanif 2002:1-2), cukup baik merepresentasikannya. Ia menyebut:

Secara umum bisa dikatakan bahwa pandangan keagamaan yang muncul dalam litaratur tafsir klasik terhadap ayat-ayat gender selama ini lebih bersifat bias keberpihakan pada laki-laki, di mana lakilaki diberikan peran dominan dalam dunia publik, sementara perempuan diberikan peran di wilayah privat. Meskipun peran demikian tepat untuk konteks sosial masa itu, pembagian peran berdasarkan jenis kelamin jelas merugikan perempuan dan menguntungkan laki-laki. Pembagian seperti ini tidak sejalan dengan semangat yang ingin ditumbuhkan oleh al-Quran.

Tidak jauh berbeda dengan literatur keIslaman klasik lain, dalam kitab tasawuf, ilmu kalam, hadis dan filsafat nuansa kelaki-lakian tambak begitu dominan. Buku Mutiara Terpendam: Perempuan Dalam Literatur Islam Klasik telah memuat bagaimana citra ideal relasi gender direpresentasikan dalam berbagai cabang keilmuan Islam klasik. Buku ini misalnya membahas Gambaran Tuhan Yang Serba Maskulin: Perspektif Gender Pemikiran Kalam, Mitos-Mitos tentang Kecantikan dan Kelembutan, Hukum Yang Memihak Pada Laki-Laki: Perempuan Dalam Kitab Fikih, dan lain sebagainya.

Ketimpangan gender, tidak dapat terelakkan, juga terlihat dalam pemikiranpemikiran tokoh besar di era modern. Tokoh-tokoh modernis Islam semisal Muhammad Abduh, Ibn Asyur, athThabatabai belum dapat bergerak jauh dari pemikir-pemikir sebelumnya mengenai relasi gender. Argumentasi relasi gender yang mereka bangun dalam karya-karyanya masih menekankan supremasi laki-laki atas perempuan (Muhammad 2001:11-13). Baik gagasan-gagasan ulama klasik maupun modern yang mendiskreditkan perempuan, pada saat bersamaan mengutamakan lakilaki, menjadi latar bagi cendekiawan muslim maupun non-muslim mutaakhir untuk mengedepankan pandangan progresif yang menghadirkan pembacaan baru berbasis kesetaraan dan keadilan gender. 
GENDER DAN REFORMASI STUDI ISLAM

Pembacaan baru terhadap wacana agama yang berhubungan dengan isu gender telah banyak dilakukan para ilmuan Islam maupun non-muslim. Reformulasi konsep gender baru ini sebagian besar tidak sejalan dengan mainstream pandangan ulama klasik maupun sebagian ulama modernis. Wacana agama yang tidak seimbang dalam menilai gender secara umum dianggap telah menodai nilai-nilai universal Islam dan terbukti menjadi salah satu alasan terhadap kemunduran peradaban Islam. Dogma tersebut terkesan membenarkan tindakan diskriminasi, marginalisasi, penindasan dan ketidakadilan terhadap perempuan yang berbasis pada perbedaan biologis atau jenis kelamin. Hal tersebut lebih jauh menyebabkan dominasi peran laki-laki dalam sektor publik, sementara peran perempuan terbatas dalam sektor demostik semata, yang tentunya sangat merugikan bagi laju peradaban dunia Islam.

Reinterpretasi ide gender dalam teksteks Islam pada dasarnya berjalan seiring dengan upaya yang dilakukan tokoh-tokoh modernis dalam mereformasi studi Islam. Charlez Khuzman melihat upaya ini sebagai rekonsiliasi pemahaman Islam dengan nilai-nilai modern termasuk di dalamnya pemberian hak-hak perempuan, pendidikan dan peradaban baru (Khuzman 2002:4). Sejalan dengan itu Abdul Mustaqim, dalam Epistemologi Tafsir Kontemporer, mejelaskan bahwa ada perubahan paradigma yang besar dalam memahami al-Quran dan hadis di era yang ia sebut sebagai reformatif dengan nalar kritis. Tokoh-tokoh masa itu banyak mengkritik pandangan ulama sebelumnya dan menawarkan cara pandang baru yang relevan dengan semangat modernisme, termasuk mengenai isu-isu gender. Epistemologi keIslaman baru dibangun dengan mengangkat spirit Islam dan memanfaatkan teori-teori sosial baru yang beberapa tidak lahir dari tubuh Islam. Perkembangan dan perubahan paradigma itu dimaksudkan untuk menyediakan solusi terkini guna transformasi sosial (Mustaqim 2012:51-53). Sebab itulah dapat dikatakan bahwa reformasi pemahaman gender dalam tubuh Islam berkembang seiring perubahan-perubahan yang terjadi dalam paradigma keilmuan Islam umumnya.

Tokoh yang mula-mula menulis tentang hal tersebut ialah Qasim Amin (w. 1908). Pria berkebangsaan Mesir ini menemukan adanya bentuk-bentuk ketimpangan sosial berbasis gender dalam kehidupan masyarakat yang didasari atas pemahaman agama yang keliru. Ia menulis dua karya besar bertajuk perempuan; Tahrir al-Mar'ah, terbit pada tahun 1899 dan AlMar'ah al-Jadidah, terbit pada tahun 1906 (kedua-duanya dihimpun menjadi satu dan diterjemahkan ke dalam bahasa Inggris oleh Samiha Sidhom Peterson).

Qasim misalnya melihat bahwa ketidakpedulian masyarakat terhadap pendidikan perempuan yang membuatnya dapat ikut terlibat dalam pengembangan peradaban serta pembangunan ekonomi menjadi alasan diperlukannya sebuah paradigma baru guna emansipasi. Pendidikan semestinya membuka ide 
persamaan hak bagi perempuan dalam berbagai aspek kehidupan masyarakat. Dalam artian itu pendidikan bukan justru melahirkan ide pengekangan yang memaksa perempuan tetap berada di wilayah domestik dan hidup dalam nestapa cengkraman laki-laki (seperti yang berlaku dalam pendidikan khusus wanita di sebagian pesantren di Indonesia) (Amin n.d.:11-16).

Pasca Qasim Amin, reformasi pemahaman gender dalam agama terus bergulir, bahkan hingga hari ini. Tokohtokoh seperti Ashgar Ali (w, 2013), Riffat Hassan, Amina Wadud, Fatimah Mernissi, Hussein Muhammad, Musdah Mulia, untuk menyebut beberapa, merupakan tokohtokoh yang berkontribusi besar dalam mereformulasi konsep Islam mengenai isuisu gender. Mereka sepakat pada sebuah kenyataan bahwa wacana-wacana agama yang merepresentasikan ketimpangan gender sebagaimana diproduksi oleh sebagian ulama dan pemikir Islam mengalami kecacatan. Lebih jauh mereka memaparkan beberapa asumsi dasar terkait proses produksi wacana gender dalam Islam pertama, para ulama secara sadar atau tidak terjebak dalam ketersituasian atau subjektifitas kelaki-lakiannya dalam proses produksi wacana gender. Kedua, wacana-wacana gender diproduksi dalam setting sosio-politik yang patriarkhi. Ketiga, meski sebagian wacana yang diproduksi kelihatan cocok untuk masa itu, dewasa ini menjadi tidak relevan seiring meningkatnya kualitas kehidupan sosial dalam bidang keamanan, nilai-nilai yang diemban (misal HAM), dan taraf pendidikan. Keempat, konsep-konsep gender dalam Islam merupakan hasil olah pikir seseorang, bukan Islam itu sendiri. Dalam artian tersebut, ia memiliki kemungkinan untuk salah dan tentunya sangat berpotensi untuk dikritik dan diperbaharui.

Abdullah Saeed dalam karyanya Reading the Qur'an in the Twenty-First Century menunjukkan sebuah contoh bagaimana pandangan ketimpangan gender yang dahulu diterima dan kemungkinan sesuai dengan konteks makro masa itu, dewasa ini sudah tidak lagi relevan (Saeed 2014:111-28). Ia mengambil perumpamaan pada QS 4: 34 dan mengeksplor penafsiranpenafsiran ulama terhadapnya. Hasilnya ia mendapatkan keseragaman penafsiran yang menjelaskan bahwa sebagian ulama memahami perempuan sebagai subordinat laki-laki dan menyatakan bahwa perempuan harus tunduk pada kewenangan laki-laki. Saeed lebih lanjut mensinyalir pemahaman ini tumbuh dalam konteks sosial, budaya, politik dan ekonomi yang patriarkhi sehingga mereka menafsirkan ayat-ayat melalui lensa itu. Adalah benar pada abad ke-7 M., otoritas sosial, politik, budaya dan ekonomi dikuasai oleh lakilaki. Al-Quran menangkap hal itu dan menyatakan bahwa perempuan berada di bawah wewenang laki-laki. Bagi generasi pertama, pengamatan ini terbilang alamiah karena sesuai dengan kondisi sosial masa itu. Sayang ulama pra-modern menangkap ayat-ayat seperti ini tidak memerlukan pertimbangan norma dan nilai yang hidup dari lingkungan wahyu aktualnya sebagai titik awal penafsiran. Alih-alih 
mengedepankan nilai keadilan, kesetaraan, kebebasan, pengakuan hak dan anti penindasan yang menjadi spirit dasar alQuran, para ulama memahami ayat ini sebagai aturan umum yang berlaku secara universal tanpa pertimbangan nilai historis.

Demikian terlihat jelas bahwa reinterpretasi wacana agama yang berlangsung turut atau bahkan dipengaruhi oleh reformasi pemahaman gender secara umum. Para pemikir berupaya meninjau ulang dan memperbaiki ide-ide sebelumnya yang terlihat usang dan berakibat buruk bagi perkembangan peradaban Islam. Berangkat dari nilai-nilai universal Islam yang disarikan dari al-Quran dan Hadis serta mengintegrasikan dengan ilmu-ilmu yang relevan, studi Islam mutakhir mencerminkan cita-cita kehidupan yang berasaskan keadilan, kesetaraaan, kebebasan, kebersamaan dan mengakui hak-hak orang lain tanpa membedakan suku, ras dan jenis kelamin. Maka oleh sebab itu, sudah seharusnya nilai-nilai dasar ini menjadi landasan utama dalam studi Islam yang dipelajari di akademi akademi manapun, tidak terkecuali pesantren.

\section{PESANTREN, WAWASAN GENDER DAN PENDEKATAN INTEGRATIF}

Penjelasan di atas memperlihatkan adanya gerak ide dalam sejarah pengetahuan Islam. Perkembangan kondisi sosial kultural mendesak orang untuk berpikir lebih maju untuk menyesuaikan diri pada kebutuhan zaman, tanpa kehilangan identitas dan nilai-nilai luhur. Masa yang bergerak memperhadapkan kepada manusia berbagai anomali terhadap penemuan dan kajian terdahulu. Islam sendiri tidak menutup diri terhadap berbagai perubahan, hal itu telah dipraktikkan oleh pemikir-pemikir progresif Islam. Al-Quran dan Hadis bersifat statis namun pemahaman atasnya bersifat dinamis. Stagnasi berpikir hanya akan membuat dunia Islam tertinggal jauh dari peradaban-peradaban lain.

Perubahan dan berkembangan peradaban Islam mesti dimulai dari lembaga-lembaga pendidikan. Sebab pendidikan memiliki daya dan otoritas untuk meninjau ulang, merevisi dan mereformulasi konsep-konsep pengetahuan sebelumnya, termasuk mengenai ide gender. Lembaga pendidikan semisal pesantren yang menjalani tradisi besar dalam hal transmisi pengetahuan Islam di Indonesia, perlu mengambil bagian dalam transformasi paradigma Islam khusunya mengenai ide gender. Ada beberapa hal yang perlu dilakukan ialah pertama, adanya kesungguhan untuk membuka diri menerima paradigma baru, dalam hal ini penulis menawarkan paradigma tauhidik sebagai fondasi. Kedua kekuatan metode penggalian ilmu dengan menyerap dan mengintegrasikan konsep-konsep yang relevan, dalam artian tida bersifat ideologis pragmatis an sich. Ketiga, mempertajam rasionalitas dan sisi kritis.

\section{Paradigma Tauhidik}

Salah satu pra-syarat dalam pengembangan keilmuan Islam ialah adanya dimensi keterbukaan (open minded) dan pembaruan diri (self renewal). Jasser Auda menjelaskan bahwa agar studi Islam 
tetap hidup maka sistem openess dalam pandangan dunia (watak kognitif) harus selalu dipelihara (Auda 2008). Dalam tradisi filsafat Thomas S. Kuhn (Kuhn 1962) memperkenalkan shifting paradigm, yaitu adanya perubahan fundamental dalam konsep-konsep dasar dan pengalaman praktis pada disiplin sains. Tegasnya perubahan paradigma terjadi ketika orang sudah mendapati anomali-anomali, teoriteori yang tidak sesuai dengan kebutuhan zaman, dalam ilmu dominan. Demikian, perubahan ilmu pengetahuan sangat dipengaruhi oleh perkembangan paradigma, termasuk kajian-kajian sosial dan Islam.

Model paradigma baru mengenai gender dalam Islam telah banyak ditawarkan oleh pemikir, salah satunya ialah Amina Wadud. Tokoh Islam progresif berkebangsaan Amerika ini menawarkan apa yang ia sebut sebagai paradigma tauhid. Pandangan integral tentang keadilan kesetaraan dan kesamaan hak dapat diperoleh dengan berpegang pada pandangan dunia tauhid. Konsep ini menjelaskan bahwa hanya Allah sosok yang maha besar dan agung yang perlu ditinggikan dan diistemewakan. Dalam artian tersebut pandangan dunia tauhid menjelaskan bahwa tidak ada superioritas manusia atas manusia yang lain di dunia (Shimogaki 2011:21-23).

Menurut Amina Wadud nilai utama yang terkandung dalam paradigma tauhid ialah keadilan. Tauhid memiliki arti penyerahan diri secara utuh kepada Allah yang Maha Esa tanpa mempertimbangkan aspek gender, politik maupun ekonomi yang melekat pada diri manusia. Sebab manusia menyadari bahwa di mata tuhan mereka semua sama dan sejajar. Di bawah paradigma tauhid inilah muncul konsep keadilan, integritas dan tanpa adanya dominasi terhadap yang lain. Lebih jauh tauhid membuka pintu kesetaraan yang harmonis antar manusia tanpa pembedaan biologis, ras, ekonomi dan politik.

Berangkat dari cara pandang tersebut, Amina Wadud meyakini bahwa paradigma tauhid sangat potensial untuk mereformasi pemahaman tradisional tentang gender. Paradigma tauhid dapat menjadi alasan teologis dan rasional untuk merevisi nilainilai yang telah terbentuk dalam dunia sosial maupun dalam tradisi agama. Lebih jauh paradigma ini dalam pengalaman praktis dapat menghapus kesenjangan gender pada semua institusi sosial keagamaan di tengah masyarakat, dalam hal wilayah pembagian kerja, politik, penguasaan ekonomi, kebebasan berekspresi dan berpendapat, ritual, penguasaan ekonomi, kesetaraan dalam hukum dan lain sebagaianya.

Dalam lingkungan pesantren, dengan demikian, paradigma tauhid harus direvitalisasi. Agar tauhid yang sebelumnya hanya bernuansa profan (duniawi) kemudian dapat memiliki agenda sosial dan transformasi. Pembelajaran tauhid tidak lagi hanya berbicara persoalan sifat dan nama Tuhan, Aqidah, atau semua yang berkaitan dengan konsep divinitas tanpa penghayatan yang lebih mendalam sehingga tercermin dalam kehidupan sosial. Dengan mengoptimalkan paradigma ini di lingkungan akademi pesantren, potensi transformasi sosial Islam akan bergulir ke 
depan. Setelah menyelesaikan studi di pesantren, perempuan akan lebih terberdayakan ke depannya, baik di bidang politik, ekonomi, teknologi, pendidikan, pertahanan dan sebagainya. Hal ini berarti, perempuan tidak lagi didominasi dan bertugas mengurus pesoalan domestik, lebih jauh perubahan ini akan berdampak pada peradaban umat Islam pada umumnya.

\section{Integrasi-interkoneksi keilmuan}

$$
\text { Dalam upaya memahami }
$$

kompleksitas kehidupan masyarakat dewasa ini, setiap disiplin keilmuan apapun tidak dapat berdiri sendiri (Abdullah 1996). Dalam artian tersebut guna memahami masyarakat dengan segenap persoalan dan nilai kehidupan yang melekat padanya hari ini seseorang tidak dapat menawarkan sebuah pandangan atau solusi dengan hanya mengandalkan satu disiplin keilmuan semata. Perlu ada sinergitas beberapa keilmuan untuk memperoleh pandangan yang menyeluruh, alih-alih atomisitik, untuk memecahkan satu atau banyak hal dalam dinamika kehidupan masyarakat.

Jasser Auda menjelaskan bahwa disiplinisasi pengetahuan seharusnya tidak menjadi penghalang dalam penggunaan konsep-konsep yang relevan dari ranahranah pengetahuan yang berbeda dalam suatu kegiatan riset (Auda 2008). Dalam artian tersebut setiap pengetahun dapat di mixing dengan pengetahun lainnya.

Hal ini berarti bahwa wacana agama mengenai gender perlu mendapatkan penjelasan dari disiplin keilmuan lain semisal sejarah dan budaya patriarkhi. Terbukanya dialog ilmu-ilmu dalam pembahasan gender ini harus dibarengi dengan menutup rapat peluang dikotomi ilmu.

Upaya integrasi keilmuan perlu dikembangkan di lingkungan pesantren khususnya ketika berhadapan dengan isuisu gender. Tindakan tersebut akan membuat pemahaman pelajar mengenai gender tidak bersifat atomistik.

Sifat keterpaduan (integrated) pengetahun ini juga merupakan semangat kompetensi utama dalam pendidikan di Indonesia, yang memadukan satu pengetahuan dengan beberapa sumber pengetahuan lainnya; dari nalar manusia (sekularisme) dan keluasan ilmu dari Tuhan dengan wahyu-Nya, sehingga semangat akan integrasi keilmuan yang dibangun pada tataran pesantren juga merupakan wujud dari semangat kompetensi utama pada pendidikan di Indonesia.

\section{Menuju Rasional dan Kritis}

Apa yang perlu dilakukan selanjutnya ialah mengedepankan budaya kritis dan rasional. Produk-produk yang dihasilkan oleh para pemikir, seluruhnya, merupakan upaya intelektual yang dihasilkan lewat lanskap pengetahuan dan kecenderungan tertentu, dalam artian tidak berangkat dari ruang vakum atau netral. Selain itu seseorang perlu membedakan antara agama dan kajian agama, antara syariah dan pemahaman syariah, antara teks dan penafsiran atas teks. Berdasarkan pegetahuan itu kita bisa menangkap bahwa selama hal tersebut bukan wahyu itu sendiri, melainkan pembacaan orang terhadapnya, ia tidak bersifat sakral dan 
profan. Artinya ia dapat dikritik dan diperbaharui sesuai konteks dan kebutuhan yang berlaku pada zaman tertentu.

Demikian teks-teks yang berbicara mengenai gender tidak dapat dilepas dari konteks asalnya. Dalam studi Islam kontemporer pelacakan perlu dilakukan dalam dua aspek yaitu asbab makro (konteks sosial ekonomi politik) dan asbab mikro (biasa didapatkan dalam asbab alnuzul dan asbab al-wurud)

Selain itu, kritik juga perlu menyasar pada integritas rawi (sanad) bahkan isi (matan). Wacana-wacana agama yang mencitrakan ketimpangan gender perlu dianalisa secara historis. Sebab pemikiran tidak lahir dari ruang hampa. Hal ini maksudnya boleh jadi pemikiran-pemikiran itu lahir dalam budaya patriarkhi.

Perbedaan sosial dan kultur menjadi alasan pentingnya upaya Kontekstualisasi terhadap isu-isu gender. Konsep-konsep gender rumusan ulama klasik yang cocok pada masa itu, dewasa ini akan terlihat bertolak belakang dari sudur pandang yang semain luas.

Karakteristik pemikiran yang muncul dewasa ini ialah mengedepankan konsep Maqasid al-Syariah (nilai-nilai universal Islam) dan pengakuan atas hak asasi manusia. Pesantren perlu mengembangkan model pembelajarannya dengan mengadopsi pemikiran-pemikiran yang lebih rasional dan kritis. Ciri khas tradisional pesantren yang mempelajari kitab-kitab klasik seyogyanya menambah dimensi lain seperti judul bukunya Hussein Muhammad "Islam Tradisional Yang Terus Bergerak".

\section{SIMPULAN}

Sebagai lembaga pendidikan Islam, pesantren menjadi gerbang bagi para pelajar Islam dahulu untuk menjadi seorang ulama. Hadirnya para ulama-ulama yang diistilahkan 'kyai' dari pesantren ini, juga menjadi pintu munculnya kitab-kitab klasik seperti halnya kitab kuning. Kita kuning ini rata-rata karangannya di dominasi oleh kalangan kyai, sehingga dipastikan hilangnya isu gender di dalam karya-karya mereka. Gender merupakan atribut yang melekat pada diri laki-laki dan perempuan yang terbentuk secara kultural. Gender membedakan struktur pada setiap aspek kehidupan tataran sosial manusia. Manusia melalui status gender ini, menciptakan sikap serta perilakunya berdasarkan jenis kelaminnya, termasuk menentukan apa yang seharusnya membedakan laki-laki dan perempuan. Keyakinan tersebut akhirnya mempengaruhi alam bawah sadar yang menyebabkan setiap analisis yang dilakukannya (kyai) baik terhadap kitabkitab karangnya, pun akan juga ikut terpengaruh.

Melihat hal ini perlunya kontruksi berpikir baru terhadap gender di lembaga pesantren. Dalam tulisan ini telah dipaparkan beberapa wacana-wacana yang menjadi pertimbangan -mungkin tidak baru- namun merefresh pikiran kita bahwa ada masalah dalam pesantren kita selama ini yang bersifat doktrinasi pada kitab-kitab kuning tersebut.

\section{DAFTAR PUSTAKA}

Abdullah, Amin. 1996. Islamic Studies Di Perguruan Tinggi: Pendekatan 
Integratif-Interkonektif. Yogyakarta: Pustaka Pelajar.

Amin, Qasim. n.d. The Liberation of Women and The New Woman, Two Documents In The History of Egyptian Feminism. edited by S. S. Peterson. Kairo: The American University in Cairo Press.

Auda, Jasser. 2008. Maqasid Al-Shariah as Philosophy of Islamic Law: A Systems Approach. London: The International Institute of Islamic Thought.

Bruinessen, Martin Van. 2012. Kitab Kuning, Pesantren Dan Tarekat. Yogyakarta: Grading Publising.

Dhofier, Zamakhsari. 1982. Tradisi Pesantren: Studi Pandangan Hidup Kyai Dan Visinya Mengenai Masa Depan Indonesia. Jakarta: LP3S.

Harahap, Rahma Riani, Pujiati Pujiati, and Ali Marzuki Zebua. 2020. "The Meaning of Word 'Al-Nisa' in Toshihiko Izutsu's Perspective of Semantic." Al Bayan 12(1):128-48.

Khuzman, Charlez, ed. 2002. Modernist Islam, 1840-1940: A Source Book. Oxford: Oxford University Press.

Kuhn, Thomas S. 1962. The Sctructure Of Scientific Revolution. Chicago: University Of Chicago Press.

Marcoes, Lies M., and Johan H. Meuleman, eds. 1993. Wanita Islam Indonesia Dalam Kajian Tekstual Dan Kontekstual: Kumpulan Makalah Seminar. Jakarta: INIS.

Marhumah, Ema. 2011. Konstruksi Sosial Gender Di Pesantren; Studi Kuasa Kiai Atas Wacana Perempuan. Yogyakarta: Lkis Pelangi Aksara.

Muhammad, Hussein. 2001. Fiqh Perempuan: Refleksi Kiai Atas Wacana Agama Dan Gender. Yogyakarta: LKiS.
Muhammad, Hussein. 2016. Perempuan, Islam Dan Negara: Pergulatan Identitas Dan Entitas. Yogyakarta: Qalam Nusantara.

Munhanif, Ali, ed. 2002. Mutiara Terpendam: Perempuan Dalam Literatur Islam Klasik. Jakarta: Gramedia Pustaka Utama dan PPIM.

Mustaqim, Abdul. 2012. Epistemologi Tafsir Kontemporer. Yogyakarta: LKiS.

Nawawi, Muhammad Ibn Umar. n.d. Uqud Al-Lujjayn Fi Bayani Huquq AlZaujayn. Jakarta: Maktabah Dar alHikmah.

Qomar, Mujamil. 2006. Pesantren: Dari Transformasi Metodologi Menuјu Demokratisasi Institusi. Jakarta: Erlangga.

Rahman, Yusuf. 2017. "Feminist Kyai, K.H. Husein Muhammad: The Feminist Interpretation on Gendered Verses and the Qur'ān-Based Activism." Al-Jami'ah: Journal of Islamic Studies 55:293-326.

Saeed, Abdullah. 2014. Reading the Quran In the Twenty-First Century: A Contextualist Approach. London: Routledge.

Shimogaki, Kazuo. 2011. Kiri Islam Antara Modernisme Dan Posmedernisme. Yogyakarta: LKiS.

Srimulyani, Eka. 2007. "Muslim Women and Education in Indonesia: The Pondok Pesantren Experience." Asia Pasific Journal of Education 27(1):85-99.

Wahid, Sinta Nuriah. 2001. Wajah Baru Relasi Suami Istri: Telaah Kitab 'Uqûd Al-Lujjayn. Yogyakarta: LkiS. 